\title{
Some geotechnical aspects of closure - case study of a thickened tailings valley storage in Western Australia
}

\author{
C.S. Hogg Coffey Mining, Australia
}

\begin{abstract}
This paper explores geotechnical aspects of closure as it relates to valley type tailings storage facilities (TSF). At closure differential settlement of the final tailings surface within a valley tailings storage facility can be problematic. As the tailings consolidate, a 'dish' is formed within the tailings storage basin, typically near the main embankment dam. The formation of a concave top surface has implications for closure of the facility as rainfall runoff can migrate through the TSF top surface cover into the deposited tailings. In addition, this may have implications with respect to the long term stability of the main embankment as factors of safety may be reduced as the pond moves towards the embankment. Investigation of a valley tailings storage in Northern Australia and subsequent consolidation analysis indicated that estimates of post closure tailings settlement for the proposed top surface cover were manageable with the likelihood of significant ponding on the TSF cover considered to be low.
\end{abstract}

\section{Introduction}

This paper explores geotechnical aspects of closure as it relates to valley type tailings storage facilities. At closure differential settlement of the final tailings surface within a valley tailings storage facility can be problematic. As the tailings consolidate, a 'dish' may be formed within the tailings storage basin, near the main embankment dam, depending on the tailings deposition strategy adopted. The formation of a concave top surface has implications for closure of the facility as rainfall runoff can migrate through (and across) the surface cover into the deposited tailings. In addition, this may have implications with respect to the long term stability of the main embankment as factors of safety may be reduced as the pond moves towards the embankment.

More recently with the use of thickened tailings disposal techniques, questions have been raised regarding differential settlement and implications for closure of valley facilities with 'store and release' covers, storing thickened tailings.

This paper presents results of studies carried out to investigate the likelihood of creating a 'dished' top surface at closure of a valley type facility storing thickened tailings. Investigations were undertaken utilising electrical friction cone probing techniques in order to assess the strength and pore pressure profile, and consolidation properties for the full depth of the tailings within the storage. The results of the probing indicated relatively uniform strength profiles across the tailings beach areas, with only minor reduction in strength, away from the main embankment toward the centre of the TSF.

The results appear consistent with thickened tailings being deposited into the facility, and indicate that the thickened tailings have achieved a relatively high density with little evidence of segregation across the tailings beaches.

Estimates of post closure tailings settlement, based on the results of the probing for the proposed top surface cover were found to be manageable, in the range of $0.1 \mathrm{~m}$ to $0.4 \mathrm{~m}$ with the likelihood of significant ponding on the TSF cover considered to be low.

\section{Background}

In the 1990s the MERIWA project (MERIWA Project No. M241, 1998) in Western Australia examined consolidation and evaporation of saline gold tailings in order to provide recommendations on the design, operation and rehabilitation of tailings storages. This study concentrated on paddock storage facilities at gold mines within Western Australia. The study revealed that the effect of evaporation on achieving higher 
tailings densities was pronounced, i.e. greater than relying on self weight alone. It was noted that without consolidation, deposited tailings would dry back from a deposited moisture content to a shrinkage limited, i.e. as revealed in the air drying test.

The data from the MERIWA project included cone penetration test (CPT) test results. Of particular note was that generally, cone resistance near the embankment for saline gold tailings ('unthickened') was in the range 2 to $5 \mathrm{MPa}$ and near the decant $2 \mathrm{MPa}$ or less. These results can be readily compared with the CPT results from this case study.

As part of the MERIWA study a computer program MinTaCo was developed by the University of Western Australian to enable coupled self weight consolidation and evaporation to be modelled. The program was used to examine filling rates and storage sizing, both aspects that could be designed into the tailings storage system.

Further comments regarding tailings consolidation can be found in Fahey and Newson (1996), which concluded that the time of consolidation is proportional to the square of the drainage path length (i.e. to $\mathrm{D}^{2}$ ), and that facilities particularly in-pit storage which were undrained, showed poor consolidation and such facilities with base drainage show higher densities.

Studies into in-pit tailings storages for laterite nickel in-pit tailings facilities have revealed that the rate of consolidation is very much influenced by drainage pathways (McDonald and Lane, 2010). Neukircher (1998) concluded that settlement of gold tailings in a impoundment had taken place more rapidly than predicted by analysis, and that this was likely due to better drainage.

The author's experience with a similar valley type tailing storage for a gold mine in the tropics which utilised traditional tailings slurry deposition with beaches developed mostly from the main valley embankment to a decant area, provided a practical example of what can be expected with tailings consolidation post closure. The site was closed in 2002 and re-commissioned in 2005. Based on site observation and comparison of surveys (i.e. contours), the beach slopes away from the main embankment were maintained over this period with the decant pond remaining situated some $\sim 100-150 \mathrm{~m}$ away from the main embankment (i.e. there was no migration of the pond towards the main valley embankment). Anecdotally, the tailings close to the embankment appear to have mostly consolidated during the operating life of the storage rather than post closure. CPT testing was performed during the life of this facility and indicated silty sands and cone resistance between 2 and $5 \mathrm{MPa}$ near the embankment (i.e. similar to the MERIWA project). The tailings had good consolidation characteristics with coefficients of consolidation $\left(\mathrm{c}_{\mathrm{v}}\right)$ greater than $4,000 \mathrm{~m}^{2} /$ year.

\section{Case study}

\subsection{Tailings storage design concept}

In this paper a case study is presented from a Western Australian base metals mine. The existing tailings storage facility (TSF) is a valley type storage facility. The studies were originally undertaken to investigate the closure of a facility with embankments raised above the original intended design crest levels. Coffey Mining (2009a, 2009b) are the primary references for the compilation of this paper.

The embankment forming the valley type storage has been constructed in stages. The Stage 1 embankment was constructed to a maximum height of $33 \mathrm{~m}$. The TSF embankment was subsequently raised by downstream construction techniques by a further $9 \mathrm{~m}$. The main embankment currently has a maximum height of approximately $42 \mathrm{~m}$.

Tailings are deposited into the facility from a tailings pipeline that surrounds much of the facility allowing tailings deposition from the valley head, sides and from the main embankment. The tailings beach to a 'central' decant facility. The tailings are deposited into the facility at $65 \%$ solids.

The main TSF embankment comprises a zoned rockfill embankment, with a HDPE liner on the upstream face. The embankment also incorporates an upstream cutoff trench backfilled with clayey borrow material. The TSF is located immediately upstream of the water storage facility (WSF) and is designed so that seepage from the TSF flows into the WSF. 


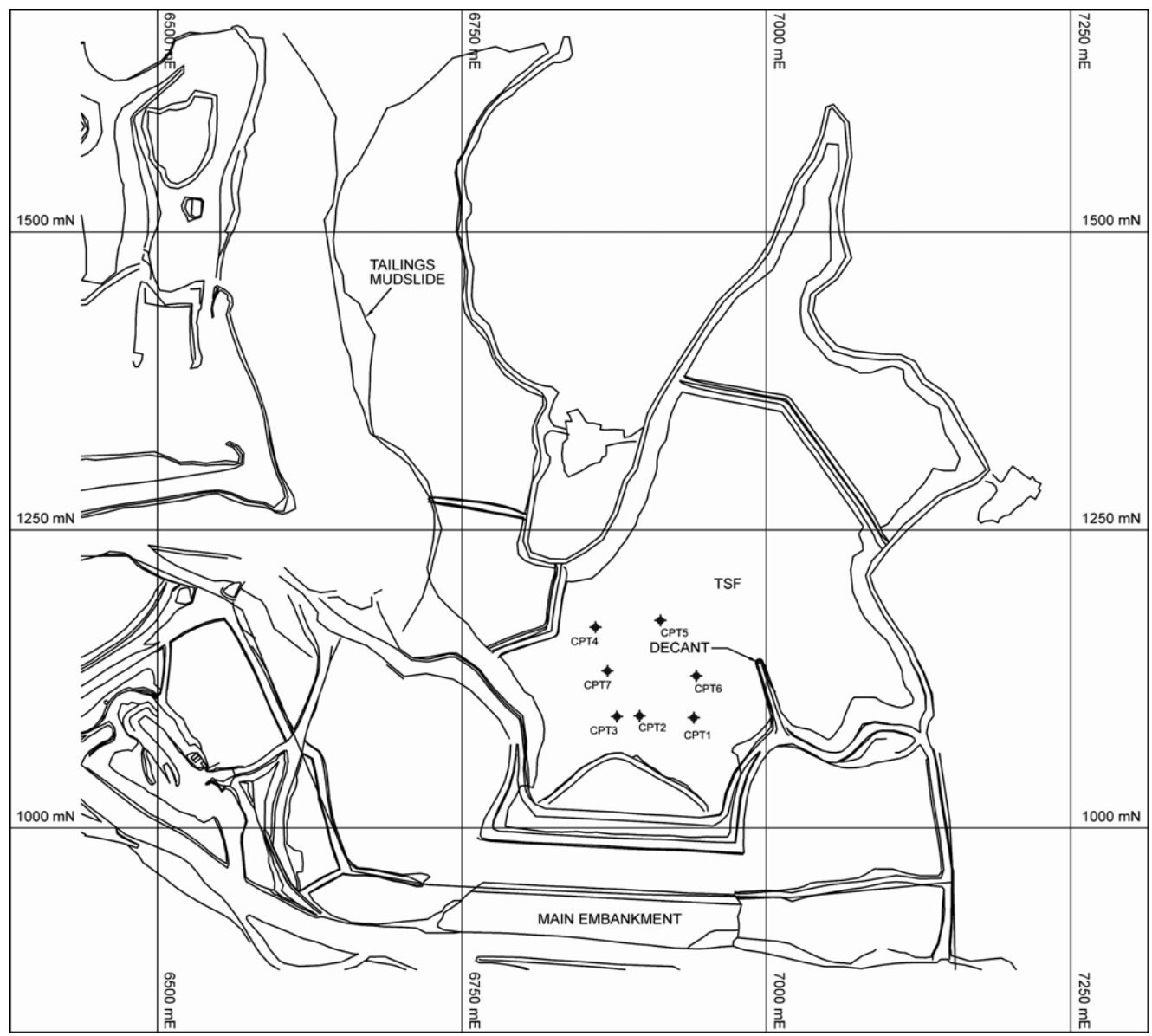

Figure 1 Site layout

\subsection{Geotechnical investigations}

\subsubsection{Prior to recent testing}

At the time of the original design (2000), tailings test work was conducted to characterise the geotechnical properties of the tailings. A summary of tailings test results from the original design assessments is provided in the table below.

Table 1 Laboratory test results $-\mathbf{2 0 0 0}$

\begin{tabular}{ll}
\hline Parameter & Result \\
\hline Undrained settling density & $1.30 \mathrm{t} / \mathrm{m}^{3}(\text { dry })^{1}$ \\
Drained settling density & $1.38 \mathrm{t} / \mathrm{m}^{3}(\text { dry })^{1}$ \\
Air drying test & $1.03 \mathrm{t} / \mathrm{m}^{3}(\text { dry })^{1}$ \\
$\mathrm{C}_{\mathrm{V}}\left(\mathrm{m}^{2} /\right.$ year $)$ & $1^{2}$ \\
$\mathrm{M}_{\mathrm{V}}\left(\mathrm{m}^{2} / \mathrm{MN}\right)$ & $2.6-3.4^{2}$ \\
Angle of internal friction $(\phi)$ & $45^{\circ 2}$ \\
\hline Note: & 1. In-house test procedures utilised, initial slurry density $48 \%$ solids. \\
2. Results based on $50 \mathrm{~mm}$ diameter CU triaxial test, initial dry density $1.7 \mathrm{t} / \mathrm{m}^{3}$.
\end{tabular}

Undisturbed tube sampling of surfacial tailings was undertaken from the tailings beaches in 2007. Laboratory testing on the samples included triaxial testing and the results of this test work are summarised in Table 2. 
Table 2 Laboratory test results $-\mathbf{2 0 0 7}$

\begin{tabular}{|c|c|c|c|c|c|c|}
\hline Sample Id & \%Fines & $\begin{array}{l}\text { Field Dry } \\
\text { Density }\left(t / \mathbf{m}^{3}\right)\end{array}$ & $\mathrm{C}(\mathbf{k P a})$ & $\phi\left(^{\circ}\right)$ & $\begin{array}{l}\mathrm{C}_{\mathrm{V}} \\
\left(\mathrm{m}^{2} / \text { year }\right)\end{array}$ & $\begin{array}{l}\mathbf{M}_{\mathbf{V}} \\
\left(\mathrm{m}^{2} / \mathbf{M N}\right)\end{array}$ \\
\hline 1 near decant & 72 & 2.14 & $30^{1}$ & $33.5^{1}$ & & \\
\hline 2 near decant & 74 & 1.94 & $62^{1}$ & $27^{1}$ & & \\
\hline 3 near embankment & 66 & 2.08 & & & & \\
\hline 4 near embankment & 62 & 2.04 & & $45^{2}$ & 1,300 & $0.1-0.06$ \\
\hline
\end{tabular}

In addition to the above testing, reconciliations of the tailings in situ density within the storage have been made at the time of the annual audits, utilising survey volumes and tailings production figures. The results of these reconciliations indicate an average tailings dry density between $1.65 \mathrm{t} / \mathrm{m}^{3}$ and $1.7 \mathrm{t} / \mathrm{m}^{3}$.

\subsubsection{In situ testing - recent electrical friction cone testing (Coffey Mining, 2009b)}

The objectives of the fieldwork were to provide additional geotechnical design parameters in order to conduct analyses with a view to closure of the facility. The parameters were also utilised in updating stability analyses, confirming liquefaction assessments and providing parameters for assessment of a TSF closure cover.

In situ testing comprised Electrical Friction Cone Penetration Tests (EFCPT) commonly referred to as CPT probes. This method was selected as an alternative to drilling and sampling, as it:

- allowed data to be collected in a relatively short space of time

- provided continuous data through the tailings profile

- utilised 'light' equipment that could traffic directly on the tailings surface therefore reducing costs.

The fieldwork was carried out in the dry season in order that the probe rig could traffic the tailings with the least restriction. At the time of the investigation the TSF embankment freeboard was approximately $2 \mathrm{~m}$ to $3 \mathrm{~m}$ and ramps were required to provide access to the TSF top surface. At the time of the fieldwork, a section of TSF was not active and had been allowed to dry for drill rig access on to the tailings beach. The tailings surface material was a silty sand material.

Seven CPT probes were carried out on the existing TSF to depths varying from nominally 11 to $29 \mathrm{~m}$ below the existing tailings surface. Eighteen (18) pore pressure dissipation tests were performed as part of the probing. The probes (CPT1 to CPT7) were advanced using a 12 tonne track truck-mounted rig supplied and operated by Probe Drill Pty Ltd. The probing was supervised by a Geotechnical Engineer from Coffey Mining. Typical probing results are shown below. It should be noted that some of the 'peaks' in the following plots reflect the probe encountering thin cemented layers. 


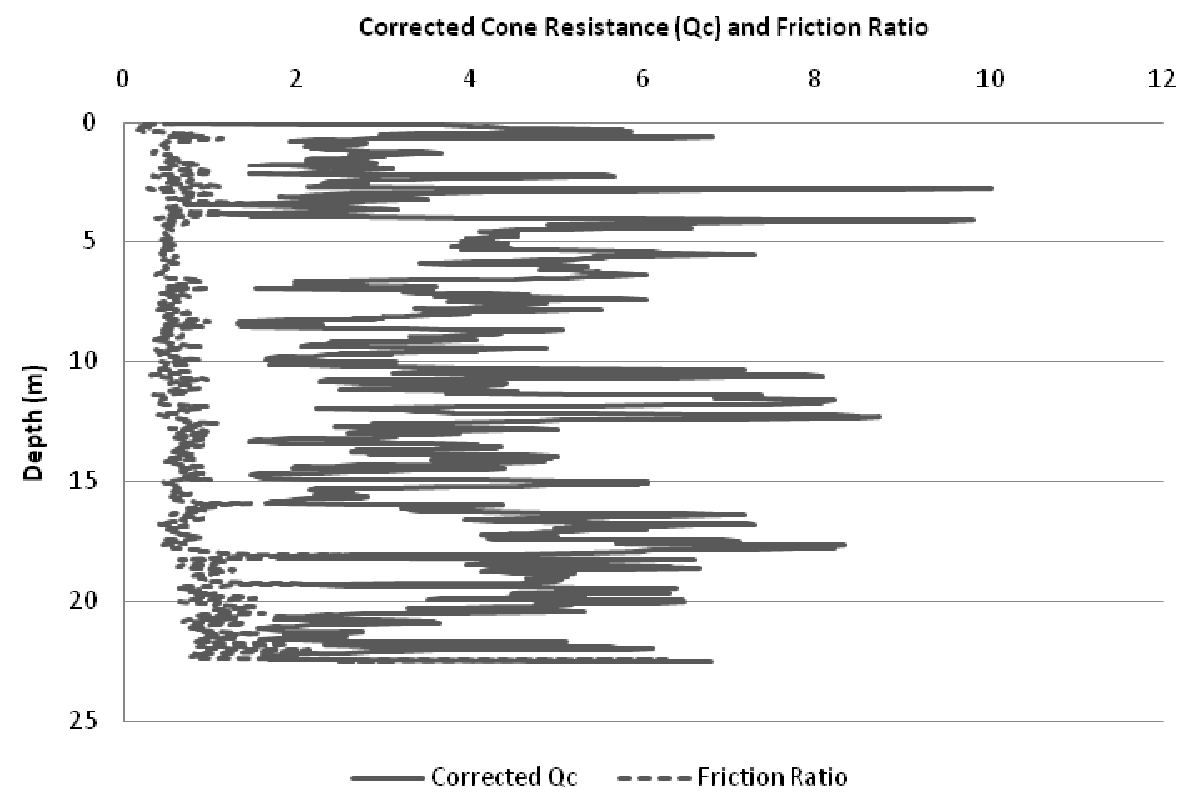

Figure 2 Typical CPT probe results

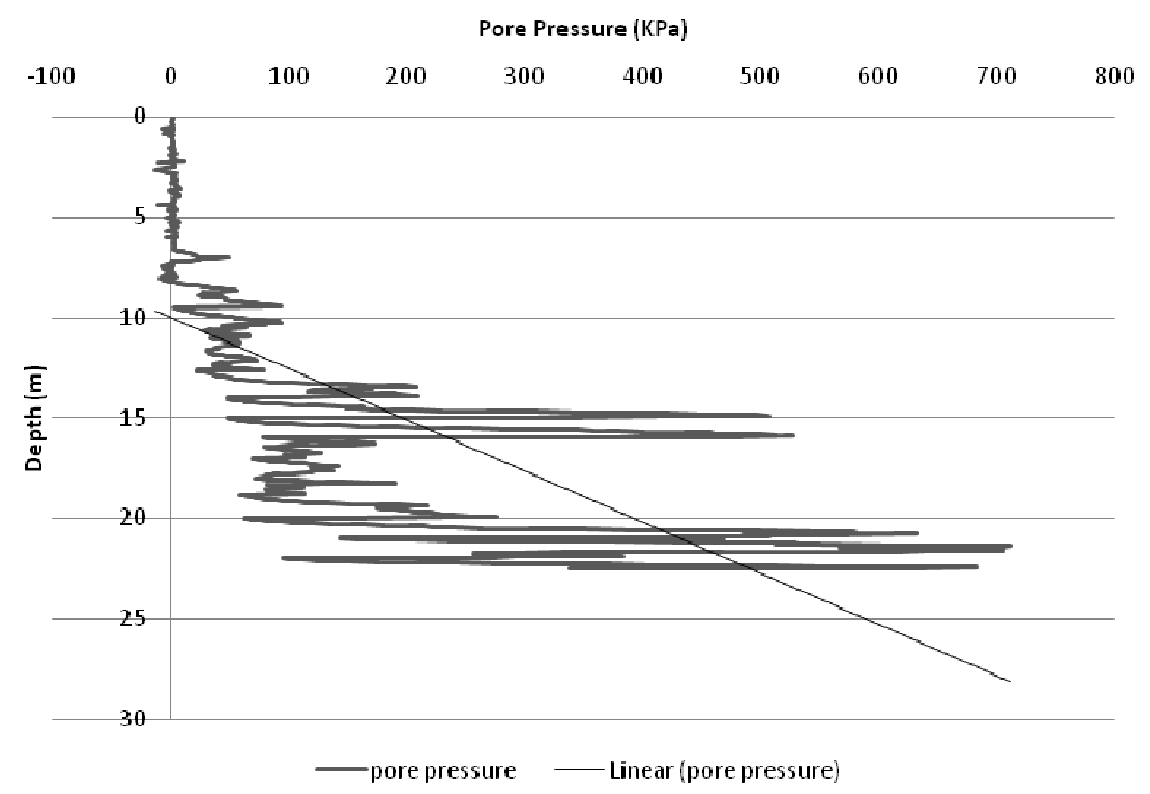

Figure 3 Typical CPT probe results-pore pressure profile

\subsection{Results of in situ testing}

CPT testing was undertaken within the existing TSF to determine the strength characteristics of the in situ tailings. Based on the CPT results, the subsurface profile encountered in the probed holes on the existing TSF generally comprised silty sand tailings to a maximum depth of $29 \mathrm{~m}$ with refusal occurring on the foundation layer of the TSF. The plots in Figure 4 summarise average probe resistance versus depth and Table 3 summarises the material parameters based on the interpretation of the CPT results (Lunne et al., 1997). The interpretation of consolidation parameters is performed by estimating the time for $50 \%$ pore pressure dissipation $\left(\mathrm{T}_{50}\right)$ from CPT piezocone data. An estimate of $c_{h}$ is obtained from curves of $\mathrm{T}_{50}$ versus $\mathrm{c}_{\mathrm{h}}$ and then $\mathrm{c}_{\mathrm{v}}$ estimated assuming a $\mathrm{c}_{\mathrm{v}}: \mathrm{c}_{\mathrm{h}}$ ratio of one. 


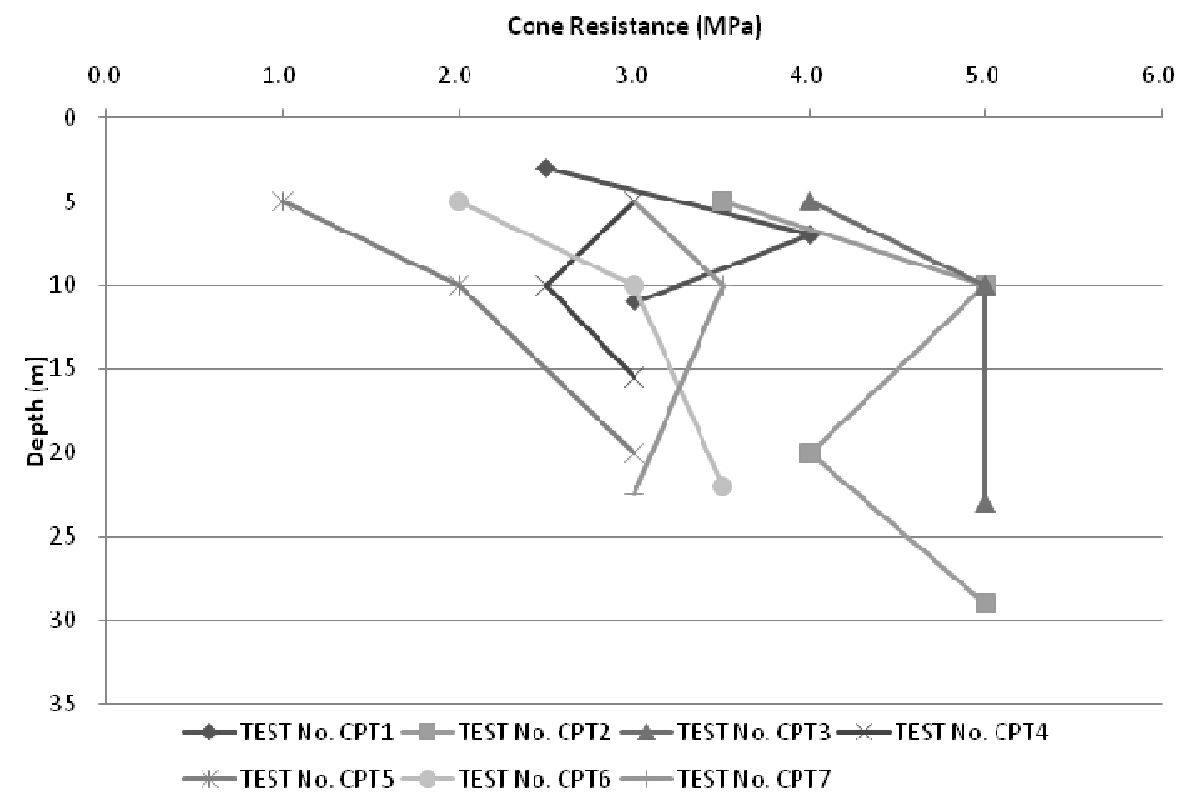

Figure 4 Probe results - interpreted cone resistance versus depth

Table 3 Summary of CPT interpretation

\begin{tabular}{lclcccc}
\hline $\begin{array}{l}\text { Probe } \\
\text { No. }\end{array}$ & $\begin{array}{l}\text { Depth to Top } \\
\text { of Unit (m) }\end{array}$ & Description & $\begin{array}{l}\text { Average Cone } \\
\text { Resistance } \\
\text { Qc (MPa) }\end{array}$ & $\begin{array}{l}\text { Friction } \\
\text { Angle } \\
\boldsymbol{\varphi} \text { ' (degrees) }\end{array}$ & $\begin{array}{l}\mathbf{T}_{\mathbf{5 0}} \\
(\mathbf{m i n})\end{array}$ & $\begin{array}{l}\mathbf{C}_{\mathbf{V}} \\
\left(\mathbf{m}^{\mathbf{2}} / \mathbf{y} \mathbf{e a r}\right)\end{array}$ \\
\hline CPT1 & $0-11.0$ & Tailings, silty sand & 3.2 & 32.9 & - & - \\
CPT2 & $0-29.0$ & Tailings, silty sand & 4.4 & 30.8 & 0.24 & 205 \\
CPT3 & $0-23.0$ & Tailings, silty sand & 4.7 & 32.3 & 1.10 & 48 \\
CPT4 & $0-15.5$ & Tailings, silty sand & 2.8 & 30.2 & 0.63 & 82 \\
CPT5 & $0-20.0$ & Tailings, silty sand & 2.0 & 27.3 & 0.27 & 182 \\
CPT6 & $0-22.0$ & Tailings, silty sand & 2.8 & 29.5 & 0.34 & 146 \\
CPT7 & $0-23.0$ & Tailings, silty sand & 3.2 & 30.2 & 0.59 & 88 \\
\hline
\end{tabular}

Note: Probes CPT 1, 2 and 3, near embankment, probes CPT 5 and 6 near decant, Probes CPT 4 and 7 'intermediate', refer to Figure 1.

The strength and friction ratios of the sandy tailings were relatively uniform, indicating an average cone resistance of between 2 and $4.7 \mathrm{MPa}$. There was an approximately $40 \%$ reduction in average cone resistance for probes near the decant pond compared to those near the embankment.

The pore pressures typically varied from nominally $0-200 \mathrm{kPa}$. The probing results indicated zero pore pressure for most of the initial top $10 \mathrm{~m}$ of the tailings. Increases in pore pressures were recorded to an average of $200 \mathrm{kPa}$, increasing with depth after $10 \mathrm{~m}$ into the tailings. The pore pressure dissipation tests indicated that the tailings drain relatively rapidly. There was no distinct trend based on the dissipation test results (i.e. $\mathrm{T}_{50}$ ) for probes near the decant pond compared to those near the embankment and hence it can be inferred that there is no trend in coefficient of consolidation $\left(\mathrm{c}_{\mathrm{v}}\right)$ with location.

\subsection{Analyses - implications for closure}

The amount of consolidation at pre-closure is related to the:

- rate of tailings rise

- tailings consolidation properties 
- drainage conditions of the consolidating tailings mass

- salinity of the tailings, which effects evaporation from the tailings surface (less significant for this case study as the process water is brackish).

The graph below details the filling rate of the TSF examined in this paper. In the first year of filling the rate of tailings rise was approximately $16 \mathrm{~m} /$ year with the rate of tailings rise decreasing to nominally $3 \mathrm{~m} / \mathrm{year}$ in year 4 and $2 \mathrm{~m} /$ year in year 5 .

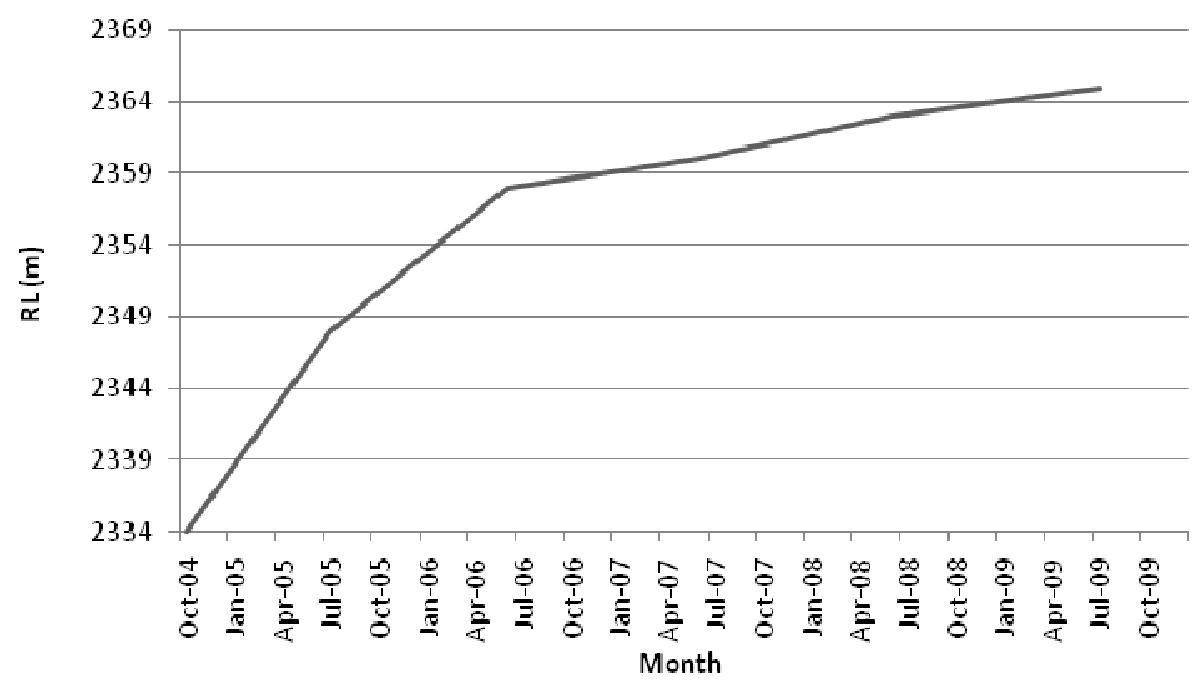

Figure 5 Tailings elevation versus time

As a 'first pass', a tailings consolidation assessment was performed using simplified methods and traditional consolidation theory (Bowles, 1988) to determine the likely consolidation time taken for the tailings to achieve $90 \%$ consolidation. Estimation of differential settlements upon de-commissioning (i.e. post closure) of the TSF was also carried out as part of the assessment.

The table below summarises the anticipated consolidation time for the tailings within the existing TSF based on the estimated coefficient of consolidation $\left(c_{v}\right)$ of $105 \mathrm{~m}^{2} /$ year, assessed from the probing results (i.e. an average from Table 3 results).

Table 4 Predicted tailings settlement time

\begin{tabular}{lccc}
\hline & $\begin{array}{l}\text { Estimated Maximum } \\
\text { Tailings Height (m) }\end{array}$ & $\begin{array}{l}\text { Assumed 1-Way } \\
\text { Drainage Path (years) }\end{array}$ & $\begin{array}{l}\text { Assumed 2-Way } \\
\text { Drainage Path (years) }\end{array}$ \\
\hline $\begin{array}{l}\text { Existing TSF } \\
\text { Proposed embankment }\end{array}$ & 30 & 8 & 2 \\
raising to RL 378 & 42 & 16 & 4 \\
\hline
\end{tabular}

The analyses indicated that the tailings in the existing TSF are approaching $90 \%$ consolidation since tailings deposition into the TSF has taken place over approximately 5 years since commissioning of the TSF, which is midway between the predicted settlement times of 2 and 8 years. Drainage conditions are expected to be between 1 and 2 way drainage.

Filling of the raised TSF, will take place over approximately 7.5 years (i.e. a rate of tailings rise of $<1.5 \mathrm{~m} /$ year) and therefore the total filling time to RL 378 (final crest level) will be approximately 13 years. The anticipated consolidation time for the tailings to achieve $90 \%$ consolidation for the proposed TSF future embankment raising is a maximum of 16 years (average 10 years). The results of the analyses of the probe results indicate that the tailings will be approaching $90 \%$ consolidation, 'immediately' before closure.

The differential settlements are expected to be in the range of $0.1-0.4 \mathrm{~m}$ based on a $2 \mathrm{~m}$ cover layer, constructed following de-commissioning of the TSF (maximum settlement nominally $0.4 \mathrm{~m}$ ). The settlement 
assessment was based on an assumed coefficient of volume compressibility $\left(\mathrm{m}_{\mathrm{v}}\right)\left(\mathrm{m}_{\mathrm{v}}=0.4 \mathrm{~m}^{2} / \mathrm{MN}\right)$. These estimates do not take into consideration the settlement caused by the tailings self weight which has already occurred given the tailings are near $90 \%$ consolidation. This analysis indicates that the tailings beaches should experience limited settlement from consolidation, post closure and that the likelihood of significant ponding on the TSF due to consolidation settlements post closure will be low.

\section{Discussion}

The textbook by Lunne et al. (1997) recommended interpretations of CPT results appear to provide conservative values of internal friction angles when compared to the results of triaxial testing for the tailings materials being examined as part of this study.

Furthermore, textbook (Lunne et al., 1997) interpretations of $C_{h}$ (i.e. $C_{v}$ derived from $C_{h}$ ) from CPT results are commonly regarded as having a half order of magnitude accuracy (+/-). CPT test results are repeatable and the interpretations of the CPT results are indicative of changes in consolidation properties within a soil profile. The CPT dissipation test results are deemed more useful than the original $\mathrm{C}_{\mathrm{V}}$ value from triaxial testing. It is noted that since 2000 there has been a growth in the adoption of 'larger' scale laboratory consolidation tests, such as the Rowe cell test which is deemed to produce more reasonable results due to use of a greater sample size than traditional triaxial test cells.

Electrical friction cone probing ( 7 no. probes) has been undertaken across the tailings storage for the full depth of the tailings. The results of the probing indicate relatively uniform strength profiles across the beach areas when compared with the MERIWA results, with only minor reduction in strength away from the main embankment toward the centre of the TSF. The results are consistent with thickened tailings being deposited into the facility, achieving relatively high density with little evidence of segregation across the tailings beaches. The reduction in strength that was recorded towards the decant area is attributed to the minor accumulation of water on the facility following the wet season ( $40 \%$ reduction, reference Section 3.3).

The $C_{h}$ values for saline gold tailings typically vary from $5-500 \mathrm{~m}^{2} /$ year, these consolidation parameters vary over a much wider rage than the thickened base metal tailings examined in more detail in this study where $C_{h}$ was found to vary from nominally $50-200 \mathrm{~m}^{2} /$ year. This may be expected for a thickened tailings storage where there is little segregation of the tailings and no trend in consolidation characteristics (i.e. $c_{v}$ ) across the TSF. The implications of this are there is a reduced likelihood of large differential settlement on these types of facilities when compared to conventional slurry systems, however, this depends on operating conditions such as filling rate.

With a view to closure of the TSF examined in the case study, future tailings will be deposited into the future raised facility in a similar manner as the tailings to date (i.e. thickened tailings from a ring main into individual cells). This approach will result in the same high settled density observed in the existing tailings storage. During the latter stages of the TSF operation, tailings will be discharged from the centre of the TSF internal cells. This tailings deposition strategy will result in a raised landform with water shedding surfaces towards the perimeter of the facility and future spillway areas.

The likelihood of significant ponding on the TSF cover due to settlement is considered low. Allowance in the final cover design should be made for grade adjustment of the cover surface to allow for differential settlement. In this case study a minimum grade adjustment of $0.1 \%$ was recommended. This is a minor allowance to ensure adequate drainage of surface runoff from the facility. In the case study, the cover will have a grade of $2 \%$ and any 'internal' drains should have a minimum grade of $0.5 \%$.

Storage settlement characteristics of valley storage should be taken into account when generating design concepts for closure. With due consideration of differential settlement, valley tailings storages lend themselves to the following closure design concepts:

- Partial wet cover option - segregation of tailings within the facility. Cover over sandy tailings near the embankment with a permanent water pond away from embankment. The pond level is controlled by the level of the outlet spillway and a 'positive' water balance. Adequate for tropical environments and traditional tailings slurry systems. Allowance for settlement generally not required in cover design. 
- Store and release cover - domed cover on the top surface with due allowance for tailings differential settlement and top surface drainage in the cover design. Adequate for monsoonal and semi arid environments.

- Water cover - water pond over the whole of the TSF basin. Tailings settlement less of an issue with this option.

- For a store and release cover system consideration of differential settlement across a TSF is important when considering the performance of the concept as differential settlement can lead to ponding and water ingress through the cover and into the tailings. Differential settlement is less of an issue for the two wet cover options because any such settlement is not likely to adversely affect cover performance.

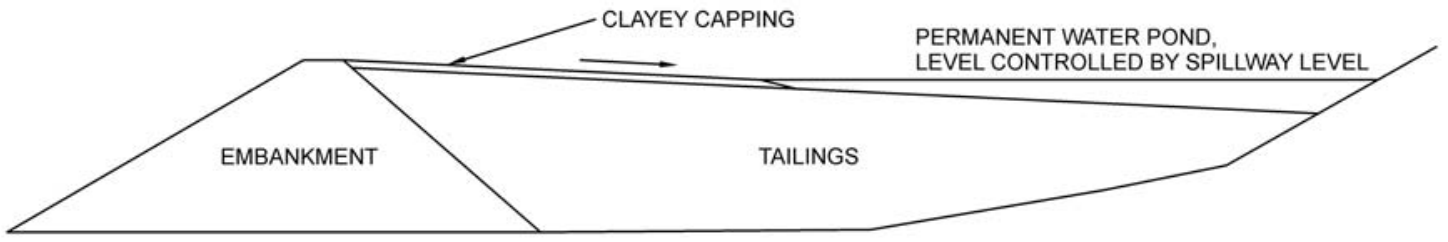

DESIGN CONCEPT - PARTIAL WET COVER OPTION

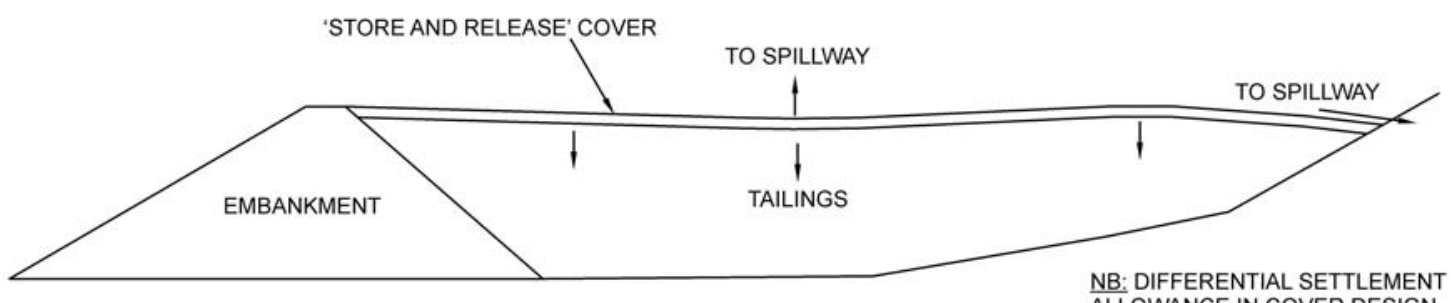

ALLOWANCE IN COVER DESIGN

DESIGN CONCEPT - DOMED STORE AND RELEASE COVER

Figure 6 Typical design concepts - TSF closure

\section{Conclusions}

CPT probing is an efficient and effective method of collecting data on consolidation characteristics of tailings. The in situ testing would need to be utilized in concert with large scale laboratory test work (i.e. Rowe cell testing or similar) for calibration of compressibility. Periodic sampling and testing during the life of the TSF to form a database of parameters provides an advantage when planning for closure.

The key to assessment of the impact on closure settlements is a proper understanding of the consolidation characteristics of the tailings. If the consolidation characteristics of the tailings and the filling rate were such that $90 \%$ consolidation was not achieved during the life of the facility then more sophisticated numerical techniques (i.e. Plaxis or similar) would need to be used to estimate the post decommissioning/closure settlements (i.e. quantity and rate).

With due consideration for differential settlement of the top surface of the tailings beaches, store and release cover systems should provide a robust solution for closure of valley tailings storage facilities, storing thickened tailings in a monsoonal or semi arid environment. Thickened Tailings experience little segregation across the tailings beach and the consolidation characteristics do not vary appreciably across the tailings beach. These good tailings characteristics lead to manageable tailings settlement/differential settlement. This in turn should lead to better closure outcomes. 


\section{Acknowledgements}

The author wishes to thank Panoramic Resources for permission to utilise the data reproduced in this paper. Also, to acknowledge the contribution of Wei Poh, project engineer, Coffey Mining who supervised the fieldwork and conducted analyses as part of the original consulting assignment.

\section{References}

Bowles, J.E. (1988) Foundation Analysis and Design, McGraw-Hill Book Company, New York, pp. 42-48.

Coffey Mining (2009a) Raising of Tailings Storage Facility RL 369 m to RL 378 m, Design Report, prepared for Panoramic Resources Limited.

Coffey Mining (2009b) Tailings Storage Facility, Geotechnical Investigation, prepared for Panoramic Resources Limited.

Fahey, M. and Newson, T. (1996) Aspects of the Geotechnics of Mine Wastes and Tailings Dams, Australian Centre for Geomechanics Workshop (powerpoint slide).

Lunne, T., Robertson, P.K. and Powell, J.J.M. (1997) Cone Penetration Testing in Geotechnical Practice, Spon Press, Taylor \& Francis Group, pp. 77-80.

McDonald, L. and Lane, J.C. (2010) Consolidation of in-pit tailings, in Proceedings First International Seminar on the Reduction of Risk in the Management of Tailings and Mine Waste (Mine Waste 2010), A.B. Fourie and R.J. Jewell (eds), 29 September - 1 October 2010, Perth, Australia, Australian Centre for Geomechanics, Perth, pp. 49-62.

MERIWA Project No. M241 (1998) Saline Tailings Disposal and Decommissioning, T.A. Newson and M. Fahey, The University of Western Australia, pp. 4.1-4.19, Fig 4.1-4.30, pp. 5.1-5.28.

Neukircher, R.J. (1998) Mine Tailings Consolidation - A Case Study, in Proceedings Fifth Annual Tailings and Mine Waste Conference, Colorado, USA, p. 297. 